\title{
Skin Rash as Presenting Symptoms of COVID-19 in a Child
}

\author{
Sujatha Manjunathan ${ }^{1}$ Jagdish Prasad Goyal ${ }^{1} \quad$ Kuldeep Singh ${ }^{1,0}$
}

${ }^{1}$ Department of Pediatrics, All India Institute of Medical Sciences, Jodhpur, Rajasthan, India

Ann Natl Acad Med Sci (India) 2021;57:123-123.

A 6-month-old male infant was admitted to our institute with a history of contact with COVID-19 positive relatives. The infant had a history of travel in a region that had registered a local surge 10 days back along with five fellow travelers from his family. The maternal uncle developed fever with myalgia after 3 days for which he tested for SARS-CoV-2 through real-time reverse transcriptase polymerase chain reaction (RT-PCR) and turned out to be positive. Therefore, upon testing of other family members because of close contact, this 6-month old infant, grandfather, and grandmother turned out to be RT-PCR COVID-19 positive. The infant's father was living in another state because of his job and was therefore, not currently staying with the patient. On admission, the infant was asymptomatic. However, on day 4 of admission, the patient developed a generalized maculopapular rash over the body, predominantly involving face and back (-Fig. 1). On the next day, the infant developed fever and diarrhea which lasted for 3 days which was managed with syrup paracetamol, zinc, and oral rehydration solution (ORS). Since the child was only experiencing mild symptoms, other laboratory investigations were not performed. The mother was tested thrice during the hospital stay and reported negative for SARS-CoV2. The infant was discharged after 7 days of an asymptomatic period.

The most common presenting symptoms of COVID-19 in the pediatric population are cough and fever. ${ }^{1}$ Skin rashes are rare in COVID-19 and only $1.8 \%$ patient from China had skin rash during COVID-19 infection. ${ }^{2}$ There is lack of data on skin rash in children with COVID-19, and it has been reported recently in the context of multisystem inflammatory disease which included erythematous, maculopapular rash. ${ }^{3}$ Skin rash as presenting symptom is very rare in children and has been reported in a single case from UK to be best of our knowledge. $^{4}$

This reports highlights the importance of clinicians being aware about the diagnosis of COVID-19 in children presenting with skin rash.

published online

July 11,2021
DOI https://doi.org/

$10.1055 / \mathrm{s}-0041-1732501$ ISSN $0379-038 X$
Address for correspondence Jagdish Prasad Goyal, MD, Department of Pediatrics, All India Institute of Medical Sciences, Jodhpur 342005, Rajasthan, India (e-mail: jpgoyal@rediffmail.com).

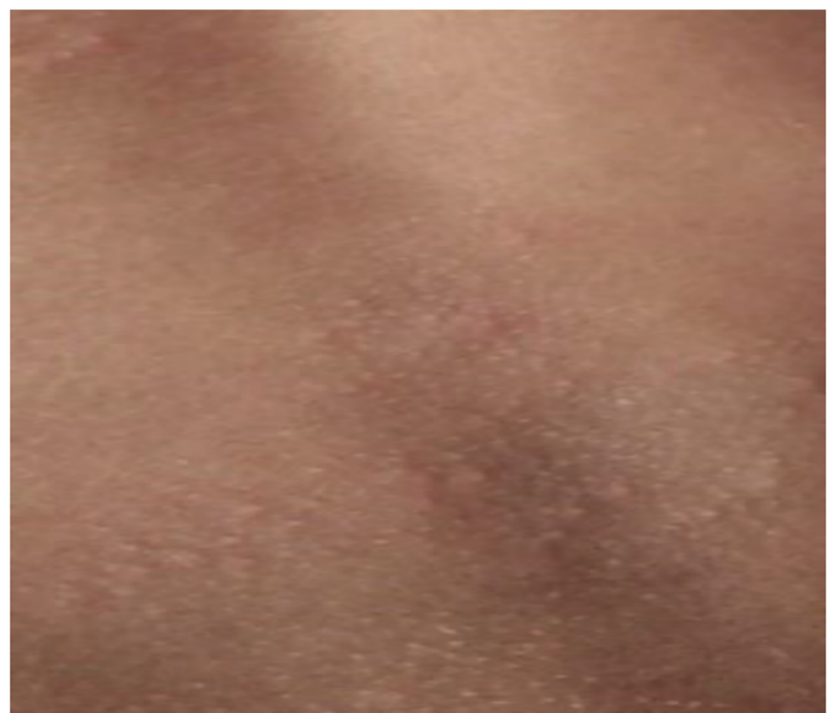

Fig. 1 Maculopapular rash in child with COVID-19.

\section{Conflict of Interest}

None declared.

\section{References}

1 Sankar J, Dhochak N, Kabra SK, Lodha R. COVID-19 in children: clinical approach and management. Indian J Pediatr 2020;87(6):433-442

2 Guan WJ, Ni ZY, Hu Y, et al. China Medical Treatment Expert Group for Covid-19. Clinical characteristics of Coronavirus disease 2019 in China. N Engl J Med 2020;382(18):1708-1720

3 Jones VG, Mills M, Suarez D, et al. COVID-19 and Kawasaki Disease: Novel Virus and Novel Case. Available at: https://hosppeds.aappublications.org/content/hosppeds/early/2020/04/06/ hpeds.2020-0123.full.pdf. Accessed June 20, 2020

4 Klimach A, Evans J, Stevens J, Creasey N. Rash as a presenting complaint in a child with COVID-19. Pediatr Dermatol 2020. Doi: $10.1111 /$ pde. 14257 (c) 2021. National Academy of Medical Sciences (India).

This is an open access article published by Thieme under the terms of the Creative Commons Attribution-NonDerivative-NonCommercial-License, permitting copying and reproduction so long as the original work is given appropriate credit. Contents may not be used for commercial purposes, or adapted, remixed, transformed or built upon. (https://creativecommons.org/licenses/by-nc-nd/4.0/).

Thieme Medical and Scientific Publishers Pvt. Ltd. A-12, 2nd Floor, Sector 2, Noida-201301 UP, India 